\title{
Phonological Adaptation of Borrowed Terms in Duramazwi reMimhanzi
}

\author{
Gift Mheta, Department of Linguistics, University of the Western Cape, \\ Bellville, Republic of South Africa (2971565@uwc.ac.za) \\ and \\ William Zivenge, African Languages Research Institute, University of \\ Zimbabwe, Harare, Zimbabwe (williamzivenge@yahoo.com)
}

\begin{abstract}
This article analyses the phonological characteristics of Shona musical terms borrowed from English. It discusses the phonological processes that take place when words are borrowed directly or indirectly from English. Essentially, the article analyses the adoption and adaptation of Shona loan-words at phonological level. It draws examples from the dictionary of Shona musical terms Duramazwi reMimhanzi (2005). This exploration of loan-word adaptation enhances the understanding of the phonological changes that the musical terms undergo during the borrowing process.
\end{abstract}

Keywords: ADOPTION, ADAPTATION, EPENTHESIS, CONSONANT, LEXICOGRAPHY, MUSIC, PHONEME, PHONOLOGY, SUBSTITUTION, VOWEL

Opsomming: Fonologiese aanpassing van ontleende terme in Duramazwi reMimhanzi. Hierdie artikel ontleed die fonologiese kenmerke van Sjonamusiekterme wat aan Engels ontleen is. Dit bespreek die fonologiese prosesse wat plaasvind wanneer woorde direk en indirek aan Engels ontleen word. Die artikel ontleed hoofsaaklik die oorname en aanpassing van Sjonaleenwoorde op fonologiese vlak. Dit neem voorbeelde uit die woordeboek van Sjonamusiekterme Duramazwi reMimhanzi (2005). Die ondersoek na leenwoordaanpassing dra by tot die verstaan van die fonologiese veranderinge wat die musiekterme tydens die ontleningsproses ondergaan.

Sleutelwoorde: OORNAME, AANPASSING, EPENTESE, KONSONANT, LEKSIKOGRAFIE, MUSIEK, FONEEM, FONOLOGIE, VERVANGING, VOKAAL

\section{Introduction}

An analysis of data drawn from Duramazwi reMimhanzi shows that English words are modified phonologically during the process of borrowing. This modification is a result of the different phonological structures existing between Shona and English. The two languages have different phoneme invento- 
ries, syllable structures and phonotactic constraints. Therefore, the rephonologization of English terms is necessary to make them fit into the phonological structure of Shona. One of the common phonological processes found in loanword adaptation is vowel substitution. To understand this process fully Shona and English vowels should be briefly described.

Shona has a simple five vowel system comprising /a, e, i, o, u/. Generally, these vowels occur in consonant vowel (CV) syllables. Shona is typically a CV language, but there are situations where some of these Shona vowels occur alone in a V syllable structure, for instance, 'who' /ani/ which is VCV in sequence. The five Shona vowels can be described as follows:
/a/ low central vowel;
/e/ mid front vowel;
/i/ high front vowel;
/o/ mid back vowel;
/u/ high back vowel.

The situation in English is much more complex. English vowels are divided into two major types, monophthongs and diphthongs. According to their manner of articulation, monophthongs refer to vowels (pure vowels) where there are no detectable change in quality during a syllable (Crystal 1997). Diphthongs are vowels that exhibit a change in quality within a single syllable (O'Grady et al. 1987). Some examples of monophthongs are [I], [e], [o:], [p], [æ], [^] and [a].

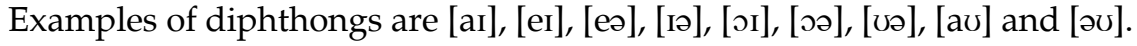

Another set of English complex vowels is called triphthongs. They refer to a type of vowel where there are two noticeable changes in quality during their production (Crystal 1997). Examples of English triphthongs are [aгə] and [агə].

The next section looks at vowel substitution as one of the rephonologization processes occurring during the borrowing of English words.

\section{Vowel Substitution}

Substitution is a term used in linguistics to refer to the process or result of replacing one item by another at a particular place in a structure (Crystal 1997). Therefore, vowel substitution is the process whereby English vowels are replaced by Shona vowels during the borrowing process (Chimhundu 2002, Zivenge 2006). This process occurs to replace English vowels that do not exist in Shona. The data below show how English vowels were substituted by Shona vowels during the borrowing process and how English monophthongs are realised in Shona as a result of rephonologization. Table 1 presents English vowels and their substitutes in Shona. 
Table 1: Vowel Substitution

\begin{tabular}{|c|c|c|c|}
\hline English Form & $\begin{array}{l}\text { English } \\
\text { Vowel(s) }\end{array}$ & $\begin{array}{l}\text { Shona Rephono- } \\
\text { logized Form }\end{array}$ & $\begin{array}{l}\text { Shona Vowel } \\
\text { Substitute(s) }\end{array}$ \\
\hline /bænd/ & $/ æ /$ & [bendi] & [e] \\
\hline /ba'su:n/ & $/ \mathrm{a} / \mathrm{and} / \mathrm{u} /$ & [basuni] & [a] and [u] \\
\hline /'kıntrI/ & $/ \Lambda /$ and $/ \mathrm{I} /$ & [kandiri] & [a] and [i] \\
\hline /'o:gən/ & $/ \mathrm{o} /$ and $/ \mathrm{\partial} /$ & [ogani] & [o] and [a] \\
\hline /ppra/ & $/ \mathrm{p} /$ and $/ \mathrm{\partial} /$ & [opera] & [o] and [a] \\
\hline /tju:bə/ & $/ \mathrm{u} /$ and $/ \mathrm{a} /$ & [t $\left.\int u \underline{b a}\right]$ & [u] and [a] \\
\hline /rI'ko:dər/ & $/ \mathrm{I} /, / \mathrm{J} /$ and $/ \mathrm{\partial} /$ & [rekoda] & [e], [o] and [a] \\
\hline
\end{tabular}

Table 1 shows that the English vowels, $/ \Lambda /$ and $/ \partial /$, are both substituted by the Shona vowel [a], which has distinctive features close to these two English vowels. They share phonetic features such as [- round], [- back] and [- front], but, in contradistinction, the Shona [a] is [+ low]. It is noteworthy that [a] is the only vowel in Shona that is [+ low]. As such, the words 'country' /'kıntri/ and 'tuba' / tju:bə/ are realised in Shona as [kandiri] and [t $\int \mathrm{uba}$ ] respectively. Similarly, / $\mathrm{p} /$ as in 'opera' /oprə/ and /o/ as in 'organ' /'o:gən / are realized in Shona as [o] as in [opera] and [ogani] respectively. The reason for this disparity is that there is no one-to-one match between English and Shona vowels. English has twenty-five vowels including pure vowels and diphthongs and Shona has five (Zivenge 2006). English vowels $/ æ /, / \mathrm{I} /, / \mathrm{\rho} /$ and $/ \mathrm{u} /$ are substituted by [e], [i], [o] and [u] in words such as 'band' /bænd/, 'violin' [vajorini], 'recorder' /rı'ko:dər/ and 'bassoon' /bə'su:n/ respectively. In all cases, the same principle of substitution takes place by using the vowels with the closest distinctive features.

This section has shown that all the English vowels not found in Shona have been replaced by Shona equivalents. The following subsection looks at vowel insertion as one of the phonological processes used to make English words fit into the phonological structure of Shona.

\section{Vowel Epenthesis / Insertion}

Epenthesis refers to a type of intrusion where an extra sound has been inserted in a word (Crystal 1997). There are two major reasons why vowels are inserted during the rephonologization process of English words into Shona. These include epenthesis to break up consonant clusters and epenthesis to open syllables. The reason for this is that Shona has no closed syllables.

Vowels in English musical terms borrowed by Shona were epenthesized in order to make them conform to the syllable structure requirements of Shona phonology. English naturally has closed syllables, a characteristic that is not shared by Shona. When exposed to the Shona phonological environment which 
has closed syllables, vowel epenthesis had to be applied to English musical terms in order to produce a phonologically acceptable output.

The next section analyses the insertion performed to break up English consonant clusters and create open syllables.

\section{Word Medial Vowel Epenthesis}

This type of epenthesis involved the insertion of vowels into the middle of words. It is also known as mid-word vowel epenthesis. It was carried out to break the cluster consonants not acceptable in Shona. Table 2 shows the words in which the vowels were epenthesized to break clusters not permissible in Shona.

Table 2: The Use of Word Medial Vowel Epenthesis in Breaking Consonant Clusters

\begin{tabular}{|l|l|l|}
\hline English Form & $\begin{array}{l}\text { Shona Rephonologized } \\
\text { Form }\end{array}$ & Epenthetic Vowel(s) \\
\hline /alegro/ & {$[$ aregiro] } & {$[\mathrm{i}]$} \\
\hline /flu:t/ & {$[$ fureti] } & {$[\mathrm{u}]$} \\
\hline /træns'fo:mər/ & {$[$ tiranzifoma] } & {$[\mathrm{i}]+[\mathrm{i}]$} \\
\hline
\end{tabular}

The data in Table 2 show that consonant clusters such as /gr/, /fl/, /tr/ and /ns/ are not allowed in Shona phonology. This can be observed in words such as [aregiro], [fureti] and [tiranzifoma] where the clusters are broken up. The data given below demonstrate the environments in which vowels are epenthesized in order to open closed syllables.

\section{Word Final Vowel Epenthesis}

Word final vowel epenthesis is vowel insertion at the end of the word. This process is also known as paragogic vowel epenthesis (Hock 1991). English words have closed syllables, while all Shona syllables are open. Therefore, word final vowel epenthesis was applied to open up the closed syllables. This is illustrated by the following examples:

Table 3: Word Final Vowel Epenthesis

\begin{tabular}{|l|l|}
\hline English Form & Shona Rephonologized Form \\
\hline /disk/ & [disiki] \\
\hline /'konet/ & [koneti] \\
\hline /klef/ & [kirefu] \\
\hline /bæs drım/ & [ besi diramu] \\
\hline
\end{tabular}


The examples in Table 3 demonstrate word final vowel epenthesis. As the data show, the epenthesized vowels are [i] and [u]. The vowel $[u]$ is followed by a labial fricative, for instance, /f/ in / klef/ that becomes [kirefu]. It can also follow a labial nasal, for instance, /m/ in /bæs drsm/ 'bass drum', which becomes [besi diramu] 'bhesi dhiramu' in Shona. An attempt to randomly epenthesize the vowels will yield unacceptable forms. Examples to this effect are ["besi diramo], [ ${ }^{*}$ disiku] and [*kirefo] for the English forms /bæs $\mathrm{dr} \wedge \mathrm{m} /$, /disk/ and [klef] respectively. ${ }^{1}$ Therefore, word final vowel epenthesis is a systematic process regulated by the language that would have borrowed words from another, which in this case is Shona. As mentioned earlier, all vowel epenthesis processes are carried out to satisfy Shona phonotactic constraints, that is, to avoid consonant clusters that are not permissible in Shona. Another phonological process commonly used in adaptation of borrowed words is consonant voicing.

\section{Consonant Voicing}

Voicing is the change of a sound from a voiceless to a voiced state. Every language has phonological sequences that it allows or disallows, that is, phonotactic constraints. This section discusses the phonotactic constraints governing the sequencing of segments in words which result from the borrowing process. Table 4 exemplifies the phonotactic constraints which manifest themselves when borrowing takes place.

Table 4: Phonotactic Constraints in Shona

\begin{tabular}{|l|l|}
\hline English Form & Shona Rephonologized Form \\
\hline /æn'tenə/ & [andena] \\
\hline /pen'tætonik/ & [pendatoniki] \\
\hline$/$ 'tmpən// & [timbani] \\
\hline /t a:nt/ & [t tandi] \\
\hline$/$ trımpət/ & [tirambeti] \\
\hline
\end{tabular}

Table 4 shows that Shona does not allow prenasalization of voiceless obstruents ${ }^{2}$ such as $/{ }^{*} \mathrm{mp} /$ and $/{ }^{*} \mathrm{nt} /$. These consonants are realized as voiced prenasalized stops, namely [mb] and [nd]. They are voiced, because in Shona all prenasalized consonants are voiced. Shona only allows voiced consonants to be prenasalized as in the examples [mb] and [nd] that are respectively realised as [timbani] and [tirambeti] on the one hand and [andena], [pendatoniki] and [t $\int$ andi] on the other.

\section{Glide Epenthesis}

This is a phonological process which entails the insertion of two glides, namely 
the palatal approximant [j] and the labiovelar glide [w]. Hock (1991) refers to these glides as semi-vowels. The insertion of these glides was a way of dealing with diphthongs and triphthongs in Shona.

\section{Epenthesis of the Palatal Approximant [j]}

The palatal approximant [j] was epenthesized in order to break diphthongs and triphthongs, which do not exist in the phonetic inventory of Central Shona. Table 5 shows the epenthesis of the palatal approximant $/ \mathrm{j} /$.

Table 5: Epenthesis of the Palatal [j] Approximant

\begin{tabular}{|l|l|}
\hline English Form & Borrowed Form (Glide Insertion) \\
\hline /æmpləfaır $/$ & [amburifaja] \\
\hline /stail/ & [t itajera] \\
\hline /vi:'əulə/ & [vijora] \\
\hline /'warələs/ & [wajiresi] \\
\hline
\end{tabular}

The examples in Table 5 capture the epenthesis of the palatal approximant [j] which was inserted to break the following / ar/ and /əu/ in the English words 'style' / starl/ and 'viola' / vi:bulə/ respectively. It was also inserted to break the triphthongs /aю/ and / аюə/ in the English words 'amplifier' /æmplə,faюr / and 'wireless' /'warolas/ respectively. The resultant forms of the insertion of the palatal approximant [j] to break both diphthongs and triphthongs are [t]itajera] 'chitayera', [vijora] 'vhiyora', [amburifaja] 'amburifaya' and [wajiresi] 'wairesi' respectively.

\section{Epenthesis of the Labiovelar Glide [w]}

The labiovelar glide $[\mathrm{w}]$ was also epenthesized to break diphthongs in the same manner as the palatal approximant [j]. It should however be noted that the epenthetic glide $[\mathrm{w}]$ appeared in a phonological environment different from that of its counterpart [j]. Table 6 shows the phonological environments in which the epenthetic glide [w] appeared.

Table 6: Epenthesis of the Labiovelar Glide [w]

\begin{tabular}{|l|l|}
\hline English Form & Shona Rephonologized Form \\
\hline /kauntarpornt/ & [kawundapojindi] 'counterpoint' \\
\hline /saund/ & [sawundi] 'sound' \\
\hline /saundtræk/ & [sawunditireki] 'soundtrack' \\
\hline /saundpru:f/ & [sawundipurufu] 'soundproof' \\
\hline /səul/ & [sowuru] 'soul' (music type) \\
\hline
\end{tabular}


The table shows that the insertion of the labiovelar glide $[\mathrm{w}]$ was carried out to break the diphthongs /av/ and /ov/ in the English words 'counterpoint' / kauntərpornt/, 'sound' /saund/, 'soundtrack' /saundtræk/, 'soundproof' /saundpru:f/ and 'soul' /səul/. The resultant forms of the epenthetic labiovelar glide [w] are [kawundapojindi], [sawundi], [sawunditireki], [sawundipurufu] and [sowuru] respectively. This epenthesis was carried out to break the diphthong /av/ and create another syllable [wu].

From the given examples, it is clear that there is a pattern of how the labiovelar glide was epenthesized in the rephonologized Shona musical terms during the borrowing process. It was epenthesized when preceding the back vowel $[u] .{ }^{3}$ The glide $[\mathrm{w}]$ was epenthesized when the vowel $[\mathrm{u}]$ was preceding it, because the two have similar distinctive features which can be presented as follows:

$$
[\mathrm{u}] \rightarrow\left[\begin{array}{l}
\text { + high } \\
+ \text { labial } \\
\text { + round } \\
\text { + syllable }
\end{array}\right] \quad[\mathrm{w}] \rightarrow\left[\begin{array}{l}
\text { + high } \\
\text { + labial } \\
\text { + round } \\
\text { - syllable }
\end{array}\right]
$$

Figure 1: Distinctive Features of $[u]$ and $[w]$

Figure 1 shows the similar distinctive features of the labiovelar $[\mathrm{w}]$ and the vowel [u] enabled epenthesis of $[\mathrm{w}]$ to be effected, as in 'sound' /saund/ which becomes [sawundi]. The only notable difference between the two segments is that the labiovelar [w] is [- syllabic], while [u] is [+ syllabic]. Glide epenthesis is therefore systematic in Shona. As shown, the insertion of the glide depends on the phonological environment.

\section{Consonant Substitution}

Consonants were substituted in the same manner as vowels. See the section on vowel substitution. Substitution was carried out to replace English consonants not existing in Shona. There are basically two English consonants not existing in the phonetic inventory of Central Shona. These are the lateral /1/ and the click /q/. The closest phonetic approximations of these two consonants are the trill or roll [r] and the velar [k]. Examples of Shona musical terms showing these consonant substitutions are [baradi] and [koteti], in which $[\mathrm{r}]$ and [k] substitute the English consonants /l/ and /q/, as in /'bælad/ and / kwo:tet/, respectively.

The given examples show that substitution is done systematically. It is only possible between consonants sharing a similar place of articulation. The English consonant $/ 1 /$ is substituted by [r] in Shona because both consonants 
are liquids. They are both apico-alveolar sounds (Crystal 1997: 23). In other words, the two consonants are articulated when the tip or end of the tongue hits the alveolar ridge. Similarly, the English consonant /q/ is substituted by $/ \mathrm{k} /$ because both are alveolar consonants.

This section has shown that there are certain phonological changes which take place when borrowed words are assimilated into Shona. In other words, occurring phonological changes serve to adapt the borrowed musical terms to the Shona language. In this process, English sounds are rendered using the closest phonological equivalents.

The examples discussed in this section are Shona musical terms borrowed from English and consequently adapted into Shona. Since English has a sound inventory different from that of Shona, the borrowed Shona musical terms had to be rephonologized to suit the phonological rules of Shona. The process of borrowing and the consequent adaptation of the Shona musical terms can diagrammatically be represented as follows:

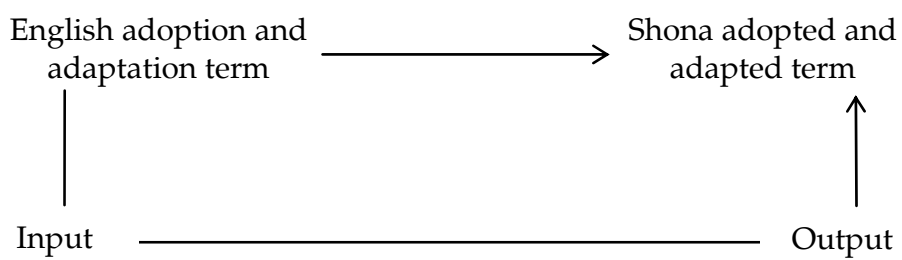

Figure 2: Adoption and Adaptation of Borrowed Terms

Figure 2 summarizes the borrowing process. It shows that when terms are borrowed from another language, which in this case is English, they are adapted to the other language, which in this case is Shona. In other words, they are made to appear like original Shona words through processes such as phonological adaptation, which includes vowel substitution, vowel epenthesis, consonant voicing, glide epenthesis and consonant substitution.

\section{Conclusion}

This article has shown how borrowing is used as a method of creating new terminology in Shona lexicography. It has illustrated the phonological processes and rules lexicographers have to be acquainted with if they are to create new terms using the borrowing strategy. The importance of borrowing in the expansion of the Shona lexicon cannot be overemphasized. It is mandatory that lexicographers acquaint themselves with the phonological rules governing the languages in which they will be carrying out their lexicographic activities. 


\section{Endnotes}

1. The asterisk marks a form that is unacceptable in Shona phonology.

2. A term used in the phonetic classification of speech sounds to refer to sounds involving a constriction which impedes the flow of air through nose or mouth, as in plosives, fricatives and affricates (Crystal 1997).

3. The authors are aware that epenthesis of the glide $[w]$ is only possible in Shona when the vowel $[\mathrm{u}]$ is preceding or following it. However, the data collected for this article can only exemplify environments in which $[\mathrm{u}]$ is preceding $[\mathrm{w}]$.

\section{References}

Chimhundu, H. 2002. Adoption and Adaptation in Shona. Oslo: Allex Project.

Crystal, D. 1997. A Dictionary of Linguistics and Phonetics. Fourth Edition. Oxford: Basil Blackwell.

Hock, H.H. 1991. Principles of Historical Linguistics. New York: Mouton de Gruyter.

Mheta, G. (Ed.). 2005. Duramazwi reMimhanzi. Gweru: Mambo Press.

O'Grady, W. et al. 1987. Contemporary Linguistics: An Introduction. London: Longman.

Zivenge, W. 2005. An Analysis of Phonological Nativisation of English Loans in Tonga. Unpublished M.A. Dissertation. Harare: University of Zimbabwe. 